\title{
Application of Lean Methodology to Increase Productivity through Value Stream Mapping
}

\author{
Engr. Joefil C. Jocson Phd ${ }^{1}$, Robert J. Tinioº \\ ${ }^{1,2}$ Nueva Ecija University of Science and Technology, Gen. Tinio Street Cabanatuan City 3100
}

\begin{abstract}
Productivity plays a vital role for business because it controls the real income that is needed to meet obligations to customers, employees, shareholders, and government through taxes and still remain competitive in the marketplace. An effective way to increase productivity is to eliminate waste in the manufacturing process, therefore using lean methodology. This study aims to use one of the lean tools which are value stream mapping (VMS) to identify wastes and improve the efficiency of the sachet filling process in manufacturing company. In conjunction with state mapping, re-engineering of the manufacturing setup was also developed. The future state map shows that after the streamlining process non value added time was reduce by $43.13 \%$. Total lead time was also reduced from $118.63 \mathrm{hrs}$ to $64.96 \mathrm{hrs}$ and total man-hours were reduced from $189.26 \mathrm{hrs}$ to $105.93 \mathrm{hrs}$ which provide significant savings to the organization with respect to labor cost.
\end{abstract}

KEYWORDS: lean methodology, productivity, value stream mapping, streamlining, lead time, man-hours

\section{INTRODUCTION}

Leonie Agri Corporation (LAC) is a company based in the Philippines, engaged in the production and processing of organic agricultural ingredients for medicinal, health and nutritional use. Located in the province of Nueva Ecija, this farm and organic manufacturing facility has grown to be the largest organic-certified farm and manufacturer of natural, organic raw materials in the country. [1] This study focuses on one of LAC main product which is called Clium Fibre, a type of food supplement from pure $100 \%$ psyllium husk.

Productivity has a crucial role to the success of industrial firms and as well as for the economic progress of the country. High productivity refers to doing the work in a shortest possible time with least expenditure in inputs without sacrificing quality and with minimum wastage of resources. One practical approach in increasing productivity in a manufacturing line is through lean methodology. [2]

Lean means means creating more value for customers with fewer resources. [3] Lean methodology was created by Taiichi Ohno and is also called the Toyota Production System (TPS). Optimizing processes to eliminate waste is crucial for the success of a company. Having wasteful activities can lower profitability, increase customer costs, decrease quality, and even employee satisfaction. For this reason, identification of the non-value adding activities and try to improve the process where they appear or ultimately eliminate them. According to TPS, there are 7 types of wastes which are inventory, motion, over-processing, overproduction, waiting, transport, and defects. [4]

One of the lean tools that can be used to eliminate waste is called value stream map or VSM. It displays all the important processes necessary to deliver value from start to finish. It allows user to visualize every process in a single glance. The main objective of VSM is to identify, demonstrate and reduce waste in the process. It can show the value added and non-value added process in a production line. VSM makes the outlines of the current and the future state of the production systems by allowing users to understand their wasteful acts and need to be eliminated. Then the users can apply lean manufacturing principles for the future state.

\section{REVIEW OF RELATED LITERATURE}

F. Nabi and R. Mahmund studied the sewing section in an apparel manufacturing company. They perform value stream mapping of a specific product in current and non value added activity was identified. There was $40.34 \%$ non value added time was eliminated using VSM and the future state map contains a cycle time of 4.684 minutes instead of 8.267 minutes. As it reduce non-value added operations, a number of labour were also reduced to 19 from 32 in the proposed state mapping. [5]

M. Habid, A. Ahsan and A. Amin used value stream mapping to identify the bottleneck process in a printing company. They able to eliminate the bottleneck processes resultin in reduction of excess motion and non-value added activity by $50 \%$. As a result, total processing time for final out was decreased. [6]

J. Rohani and S. Zahraee used value stream mapping to improve the productivity of the manufacturing line in a color industry. They develop a map for identification and elimination by using team formation, product selection, 


\section{"Application of Lean Methodology to Increase Productivity through Value Stream Mapping"}

conceptual design and time-frame formulation through takt time calculation. Based on the future VSM, final results showed that by implementing some lean thinking techniques, production lead time decrease from 8.56 days to 6 days, and the value added time decreases from 68 minutes to 37 minutes. [7]

\section{OBJECTIVE}

This study aims to put into practice one of the lean manufacturing tools, the value stream mapping (VSM) and to re-engineering the sachet filling process of Clium Fibre in LAC Company to reduce non value adding cost, reduce lead time in the shopfloor and save in labour cost.

\section{METHODOLOGY}

Data collection was conducted at every work station to document the operations for each process for one batch of Clium Fibre. The starting and ending time of each process were recorded. The activities at each process were subdivided and the layout of the working space was also analysed. A current value stream map (VSM) is generated from the data gathered.

To minimize the non value added activities and simultaneously maximize or sustain the value added activities, streamlining of the printing process and sachet filling process was done. An elevated platform was fabricated to increase the height of the sachet filling machine output is in proper level with the conveyor machine. A slide-like track was also fabricated to connect the sachet filling machine output onto the conveyor.

The starting and ending time of each process were again analyzed after the re-engineering and implementation of the streamlining. Future value stream map of sachet filling process was generated and analyzed. Percentage difference of the current and future lean matrix was compared. Change in total lead time and total man-hours was determined and analyzed.

\section{RESULTS AND DISCUSSION}

Figure 1 shows the current value stream map of the sachet filling process of the LAC Company

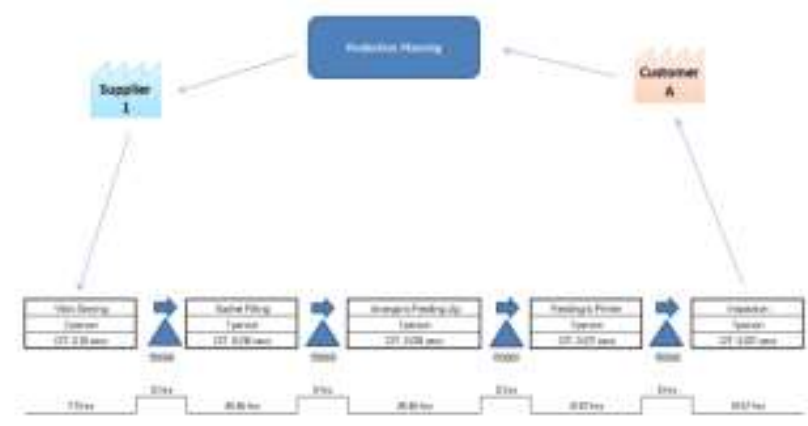

Figure 1. Current Value Stream Map

Table 1 shows the lean metrics findings from current state map of sachet filling process
Table I. Current Lean Matrix

\begin{tabular}{lll}
\hline Activity Category & Process Detail & $\begin{array}{l}\text { Time } \\
\text { (hrs) }\end{array}$ \\
\hline Value Added & Vibro Seiving & 7.5 \\
Value Added & Sachet Filling & 45.46 \\
Non Value Added & Arrange to Feeding Jig & 45.46 \\
Non Value Added & Feeding to Printer & 41.67 \\
Non Value Added & Waiting for Next Process & 12 \\
Non Value Added & Waiting for Next Process & 12 \\
Unavoidable Non & Inspection & 41.67 \\
Value Added & & \\
\hline
\end{tabular}

Processing time (value added and unavoidable non value added $)=94.63 \mathrm{hrs}$

Retention Time (non value added $)=111.13 \mathrm{hrs}$

Lead Time $=$ Processing time + Retention Time $=205.76 \mathrm{hrs}$ Percentage of value adding time $=52.96 / 205.76=25.73 \%$

Percentage of non value adding time $=111.13 / 205.76=$ $54.00 \%$

Percentage of unavoidable non value added time $=$ $41.67 / 205.76=20.25 \%$

Figure 2 shows a summary of the sachet filling process current state map.

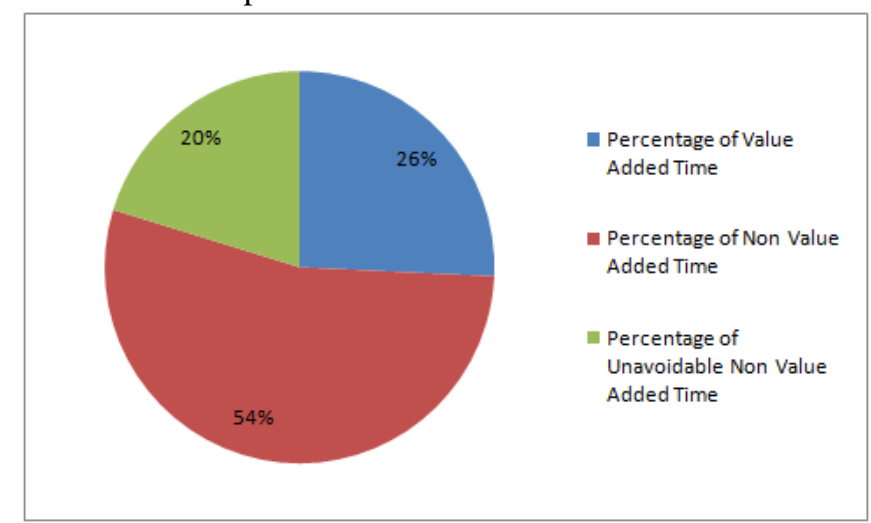

Figure 2. Sachet Filling Current State Map Summary

Figure 3 shows the setup that was developed in the sachet filling process of LAC after re-engineering. The slide-like track acts as a guide to the sachet as it falls out from the sachet filling machine onto the conveyor machine.

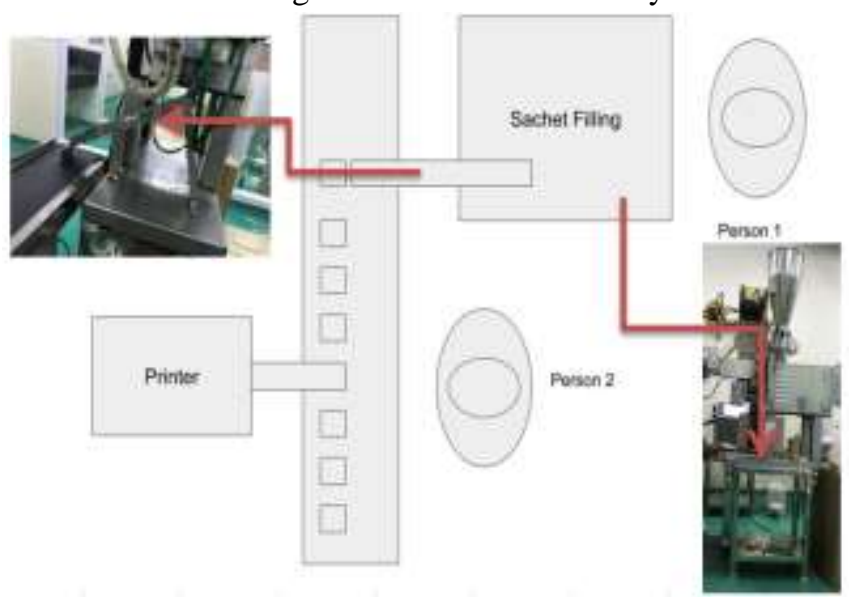

Figure 3. Process Setup after Re-Engineering 
The future flow of activities after the implementation of streamlining can be seen below in figure 4 .

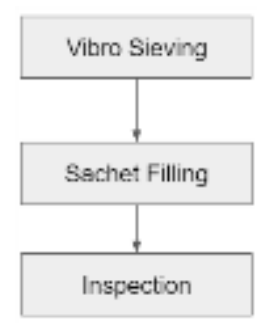

Figure 4. Process Flow After Streamlining

Figure 5 shows the future value stream map of the sachet filling process after the re-engineering and streamlining process.

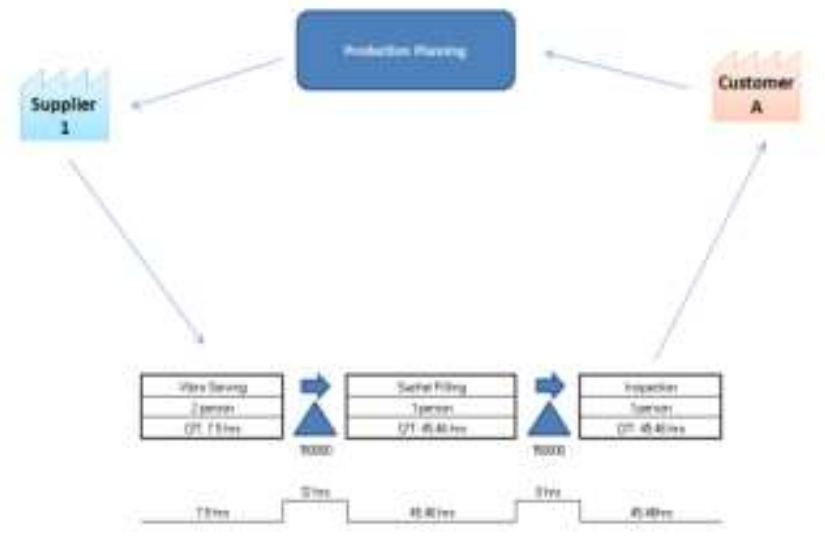

Figure 5. Future Value Stream Map

Table II shows the lean metrics findings from future state mapping.

Table II. Future Lean Matrix

\begin{tabular}{lll}
\hline Activity Category & Process Detail & $\begin{array}{l}\text { Time } \\
\text { (hrs) }\end{array}$ \\
\hline Value Added & Vibro Seiving & 7.5 \\
Value Added & Sachet Filling & 45.46 \\
Non Value Added & Waiting for Next Process & 12 \\
$\begin{array}{l}\text { Unavoidable Non } \\
\text { Value Added }\end{array}$ & Inspection & 45.46 \\
\hline
\end{tabular}

Processing time (Value added and unavoidable non value adding $)=98.42 \mathrm{hrs}$

Retention Time (Non value adding activity) $=12 \mathrm{hrs}$

Lead Time $=$ Processing time + Retention Time $=110.42 \mathrm{hrs}$ Percentage of value adding time $=52.96 / 110.42=47.96 \%$

Percentage of non value adding time $=12 / 110.42=10.87 \%$

Percentage of unavoidable non value added time = $45.46 / 110.42=41.17 \%$

Figure 6 shows a summary of the sachet filling process future state map.

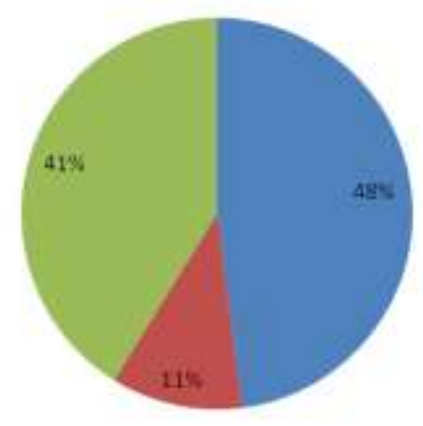

a Percentage of value Added Time

- Percentage of Non Value Added Time.

= Percentage of Unavoidable Non Value Added Time

Figure 6. Sachet Filling Future State Map Summary

Table III. Current and Future Lean Matrix Summary

\begin{tabular}{|c|c|c|}
\hline Description & $\begin{array}{l}\text { Current } \\
\text { State }(\%)\end{array}$ & $\begin{array}{l}\text { Future } \\
\text { State }(\%)\end{array}$ \\
\hline $\begin{array}{l}\text { Percentage Value Added } \\
\text { Time }\end{array}$ & 25.73 & 47.96 \\
\hline $\begin{array}{l}\text { Percentage Non Value } \\
\text { Added Time }\end{array}$ & 54.00 & 10.87 \\
\hline $\begin{array}{l}\text { Percentage of Unavoidable } \\
\text { Non Value Added Time }\end{array}$ & 20.25 & 41.17 \\
\hline
\end{tabular}

Table III shows that the percentage of the non value added time decreased by $43.13 \%$ after the implementation of lean methodology in the future state.

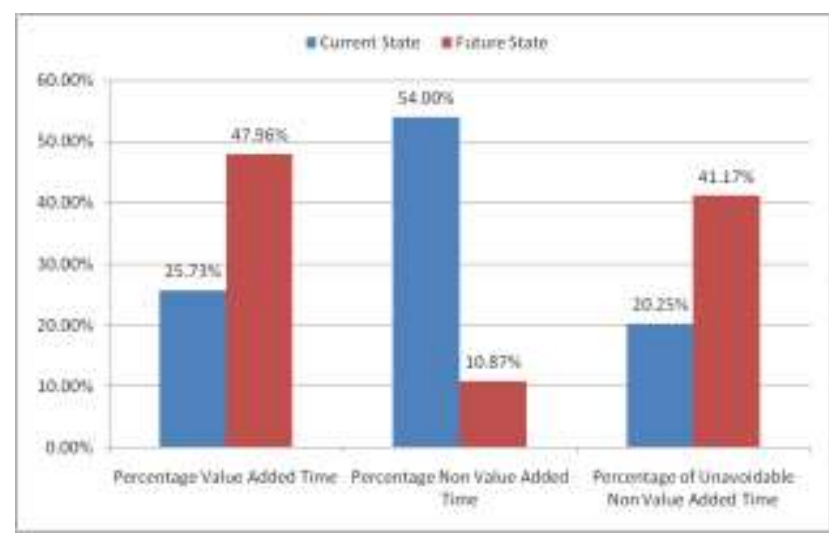

Figure 7. Current vs Future Lean Matrix Percentage

Table IV shows the total lead time and total man-hours in the current and future state value stream map.

Table IV. Current and Future State Total Lead Time and Total Man-hours

\begin{tabular}{llll}
\hline Description & $\begin{array}{l}\text { Current } \\
(\mathbf{h r s})\end{array}$ & State & $\begin{array}{l}\text { Future } \\
\text { (hrs) }\end{array}$ \\
\hline Total Lead Time & 118.63 & 64.96 & \\
Total Man-hours & 189.26 & 105.92 & \\
\hline
\end{tabular}

Total lead time for one batch was reduced from 118.63 hrs to $64.96 \mathrm{hrs}$ after future state mapping. Also, total manhours were reduced from $189.26 \mathrm{hrs}$ to 105.92 which provide significant savings to the organization with respect to labor cost. 


\section{CONCLUSIONS}

Value stream mapping (VMS) is an effective lean manufacturing tool to identify waste in a real production line but other tools should also be used in conjunction like streamlining to effectively minimize non value adding cost, increase the productivity and reduce labor cost in a manufacturing plant.

\section{ACKNOWLEDGMENT}

The authors would like to extend their appreciation to President Antonio C. Causing of the Leonie Agri Corporation (LAC) for the use of materials and facilities.

\section{REFERENCES}

1. Leonie Agri Corporation (n.d.) http://www.leonieagricorp.com/about-lac/

2. S. Kumar, N. Suresh, Production and Operations Management, 2nd Ed. New Age International Publishers, New Delhi, India (2008)

3. L. Wilson., How to Implement Lean Manufacturing, McGraw Hill, USA 2010

4. T Ohno, Toyota Production System: Beyond Large Scale Production, Productivity Press, New York (1988)

5. F. Nabi and R. Mahmund. "Elimination of Non Value Adding Activity in Sewing Section of an Apparel Industry Through Value Stream Mapping Analysis." International Journal of Engineering Research and Technology (IJERT) Vol 3. Issue 12, December 2014: pp 994 -948

6. M. A. Habib, A.M. Ahsan, and M. B. Amin, "Improving Productivity of Apparel Manufacturing System using Value Stream Mapping and Production Control Tools Focusing on Printing Section", International Journal of Research in Engineering and Technology, Volume 02 Issue 09 Sep 2013, pp. 586 - 592.

7. J. M. Rohani and S M Zahree, "Production Line Analysis via Value Stream Mapping: A Lean Manufacturing of Color Industry", Procedia Manufacturing 2 (2015). pp 6-10. 